\title{
Performance of coconut (Cocos nucifera L.) hybrids for yield and quality in the Utkal plain region of Odisha state, India
}

\author{
S.C. Sahoo, S. Sumitha ${ }^{1 *}$, A.K. Karna, G. Mishra and H.P. Maheswarappa ${ }^{1}$ \\ AICRP on Palms, College of Agriculture (OUAT), Bhubaneswar-751 003, Odisha, India \\ ${ }^{1}$ ICAR-Central Plantation Crops Research Institute, Kasaragod-671 124, Kerala, India
}

(Manuscript Received: 05-10-2020, Revised: 07-06-2021, Accepted: 30-06-2021)

\begin{abstract}
Cocos nucifera L. is a perennial oil yielding crop with a long productive life span ( $>60$ years); thus, identifying a suitable high yielding hybrid to a particular agro-climatic region plays a prime role in achieving sustainable coconut yield. In this context, an evaluation trial with varietal cross combinations involving Tall $\times$ Dwarf (six crosses) and Dwarf $\times$ Tall (two crosses) was conducted at All India Coordinated Research Project (AICRP) on Palms, Bhubaneshwar Centre, Odisha, for 15 years. The experiment was laid out in randomized block design with four replications maintaining six palms per replication. Observations on yield and yield attributing characters during 2018 to 2020 revealed the superior performance of ECT $\times$ GBGD (99.1 nuts), which was followed by ECT $\times$ MYD (86.9 nuts) over the local check (ECT) by recording higher nut yield. Copra output per palm was significantly the highest under ECT $\times$ GBGD $\left(20.6 \mathrm{~kg} \mathrm{palm}^{-1}\right)$, followed by LCT $\times$ COD $\left(18.6 \mathrm{~kg} \mathrm{palm}^{-1}\right)$. Hybrids possessed a higher quantity of organoleptically 'good' tender nut water $\left(270.3\right.$ to $354.1 \mathrm{~mL}$ ) with TSS of 5.8 to $6.9^{\circ}$ Brix, 25.4 to 34.0 ppm of sodium and 2065.9 to $2885.0 \mathrm{ppm}$ of potassium.
\end{abstract}

Keywords: Coastal, coconut, hybrids, tender nut water, yield

\section{Introduction}

Coconut (Cocos nucifera L.) is one of the important plantation crops in Odisha state, India. The major area is confined to five districts, i.e., Puri (9468 ha and 837 lakh nuts ha ${ }^{-1}$ ), Cuttack (5563 ha and 360 lakh nuts ha-1), Ganjam (5163 ha and 267 lakh nuts ha ${ }^{-1}$ ), Nayagarh (4853 ha and 361 lakh nuts ha-1) and Khurda (3638 ha and 255 lakh nuts ha $\left.^{-1}\right)(\mathrm{CDB}, 2020)$. East Coast Tall (ECT) is the dominant variety under cultivation in the state, with an average yield of 80 nuts palm ${ }^{-1}$ year $^{-1}$. Tall cultivars are mainly grown for copra and oil purposes, while dwarfs are preferred for tender nuts. The coconut hybridization programmes aim to develop heterosis for traits such as early flowering and bearing, more nuts with high copra content and wider adaptability to different agro-climatic regions. So far, hybrid evaluation trials conducted involve inter-varietal crosses of Tall $\times \operatorname{Dwarf}(\mathrm{T} \times \mathrm{D})$ and
Dwarf $\times$ Tall $(\mathrm{D} \times \mathrm{T})$ types. The superiority of hybrids over local tall cultivars in terms of early flowering, number of nuts per ha and copra per nut were established (Satyabalan and Vijayakumar, 1982; de Taffin et al., 1991). The expression of hybrid vigour is influenced by environmental factors (Chapman et al., 2000). Hence, the evaluation of hybrids in different locations is necessary to ascertain their suitability to particular vicinity. A good number of $\mathrm{T} \times \mathrm{D}, \mathrm{D} \times \mathrm{T}$ and Tall $\times$ Tall $(\mathrm{T} \times \mathrm{T})$ hybrid combinations have been developed and evaluated over the years in different locations viz., Kerala (Jerard et al., 2015), Assam (Nath et al., 2017), Coastal Andhra Pradesh (Ramanandam et al., 2017), Tamil Nadu (Vijay et al., 2017), Maharashtra (Shinde et al., 2018) and Karnataka (Sumitha et al., 2020) and released (Table 1). The productivity level in the coconut growing regions of Odisha is very low compared to the national average because of the pervasiveness of local tall variety coupled with

*Corresponding Author: sumithasundaram12@gmail.com 
non-adoption of scientific production technologies. Identifying suitable coconut hybrids to a particular agro-climatic region plays an important role in achieving higher and sustained yield. As the development of new varieties is a long-term process, the immediate step is to evaluate already released hybrids to assess their suitability for yield and tender nut water. Keeping these points in view, the present investigation was carried out for identifying better performing coconut hybrids $(\mathrm{T} \times \mathrm{D}$ and $\mathrm{D} \times \mathrm{T})$ for cultivation in Uktal Plains of Odisha.

\section{Materials and methods}

A set of eight hybrids maintained at the All India Coordinated Research Project on Palms, at Bhubaneswar, situated at $20.15^{\circ} \mathrm{N}$ latitude, $85.5^{\circ} \mathrm{E}$ longitude and at an altitude of $25.9 \mathrm{~m}$ above MSL. The soils are the loamy sand (textural class) type with a $\mathrm{pH}$ of 5.8 and impeded drainage. The mean maximum temperature ranges from 28.1 to $38.8^{\circ} \mathrm{C}$, and the minimum temperature ranges from 11.9 to $27.2^{\circ} \mathrm{C}$. The average rainfall during experimentation was $1450 \mathrm{~mm}$, of which about 80 per cent was received during the monsoon season from June to October. The hybrid cross combinations included released hybrids viz., VHC1 (ECT × MGD), $\mathrm{VCH} 2$
$($ ECT $\times$ MYD), Godavari Ganga (ECT $\times$ GBGD), Chandra Laksha $(\mathrm{LCT} \times \mathrm{COD})$, Laksha Ganga $($ LCT $\times$ GBGD), Konkan Bhatye Coconut hybrid 1 $($ GBGD $\times$ ECT), Kera Sree $($ WCT $\times$ MYD $)$, GBGD $\times$ PHOT, which was received from ICAR-CPCRI, Kasaragod and AICRP on Palms, Veppankulam Centre along with East coast Tall (ECT) as local check planted during 2005 and evaluated for yield performance till 2020. The details of parents are presented in Table 1. The hybrids and check were planted with a $7.5 \times 7.5 \mathrm{~m}$ (with a density of 175 palms $\mathrm{ha}^{-1}$ ) in a randomized block design with four replications@6 palms per replication under irrigated conditions.

Morphological characters related to leaf, inflorescence, fruit and fruit characters, tender nut quality, viz. volume of water (mL), TSS ( ${ }^{\circ}$ Brix), total sugars (g $\left.100 \mathrm{~mL}^{-1}\right)$, sodium (ppm) and potassium (ppm) were recorded in the adult palms during 2018-19 at the age of 15 years. Data pertaining to nut production and estimated copra out turn recorded from 2014 to 2020 (six years) was used for assessing the performance of the hybrids. The yield (nuts palm ${ }^{-1}$ year $^{-1}$ ) was recorded periodically during each harvest from July to June and pooled to get the yield palm ${ }^{-1}$ year $^{-1}$.

Table 1. Details of parental palms used in hybridization programme

\begin{tabular}{|c|c|c|}
\hline $\begin{array}{l}\text { Hybrid cross } \\
\text { combination }\end{array}$ & Parental information & $\begin{array}{l}\text { Hybrid and } \\
\text { year of release }\end{array}$ \\
\hline $\mathrm{ECT} \times \mathrm{MGD}$ & $\begin{array}{l}\text { Selection from East Coast Tall as female parent and Malayan Green Dwarf } \\
\text { as male parent }(T \times D \text { cross })\end{array}$ & VHC 1 (1982) \\
\hline $\mathrm{ECT} \times \mathrm{MYD}$ & $\begin{array}{l}\text { Selection from East Coast Tall as female parent and Malayan Yellow Dwarf } \\
\text { as male parent }(T \times D \text { cross })\end{array}$ & VHC 2 (1988) \\
\hline $\mathrm{LCT} \times \mathrm{COD}$ & $\begin{array}{l}\text { Selection from Laccadive Ordinary as female parent and Chowghat Dwarf } \\
\text { Orange as male parent }(\mathrm{T} \times \mathrm{D} \text { cross })\end{array}$ & Chandra Laksha (1985) \\
\hline $\mathrm{LCT} \times \mathrm{GBGD}$ & $\begin{array}{l}\text { Selection from Laccadive Ordinary as female parent and Gangabondam } \\
\text { as male parent }(\mathrm{T} \times \mathrm{D} \text { cross })\end{array}$ & Laksha Ganga (1989) \\
\hline WCT $\times$ MYD & $\begin{array}{l}\text { Selection from West Coast Tall as female parent and Malayan Yellow } \\
\text { Dwarf as male parent }(T \times D \text { cross })\end{array}$ & Kera Sree (1992) \\
\hline $\mathrm{ECT} \times \mathrm{GBGD}$ & $\begin{array}{l}\text { Selection from East Coast Tall as female parent and Gangabondam } \\
\text { as male parent }(T \times D \text { cross })\end{array}$ & Godavari Ganga (1992) \\
\hline $\mathrm{GBGD} \times \mathrm{ECT}$ & $\begin{array}{l}\text { Selection from Gangabondam as female parent and East Coast Tall as } \\
\text { male parent }(D \times T \text { cross })\end{array}$ & $\begin{array}{l}\text { Konkan Bhatye Coconut } \\
\text { Hybrid 1(2007) }\end{array}$ \\
\hline GBGD $\times$ PHOT & $\begin{array}{l}\text { Selection from Gangabondam as female parent and Philippines Ordinary } \\
\text { Tall as male parent }(\mathrm{D} \times \mathrm{T} \text { cross })\end{array}$ & Vasista Ganga (2014) \\
\hline ECT & Local check & ECT \\
\hline
\end{tabular}


Table 2. Performance of coconut hybrids for growth parameters

\begin{tabular}{|c|c|c|c|c|c|}
\hline $\begin{array}{l}\text { Hybrid cross } \\
\text { combination }\end{array}$ & $\begin{array}{c}\text { Palm height } \\
\text { (m) }\end{array}$ & $\begin{array}{c}\text { Girth at } 1 \mathrm{~m} \\
\text { height } \\
(\mathrm{cm})\end{array}$ & $\begin{array}{c}\text { No. of functional } \\
\text { leaves } \\
\text { (crown) }\end{array}$ & $\begin{array}{c}\text { Annual leaf } \\
\text { production } \\
\text { (Nos.) }\end{array}$ & $\begin{array}{l}\text { Petiole length } \\
\text { (cm) }\end{array}$ \\
\hline $\mathrm{ECT} \times \mathrm{MGD}$ & 4.4 & 90.9 & 33.0 & 12.7 & 150.6 \\
\hline $\mathrm{ECT} \times \mathrm{MYD}$ & 4.9 & 100.4 & 32.0 & 12.7 & 153.0 \\
\hline $\mathrm{LCT} \times \mathrm{COD}$ & 4.3 & 86.9 & 31.5 & 12.8 & 153.4 \\
\hline LCT $\times$ GBGD & 4.3 & 100.5 & 31.9 & 12.5 & 152.9 \\
\hline WCT $\times$ MYD & 4.3 & 90.5 & 32.4 & 12.8 & 151.1 \\
\hline ECT $\times$ GBGD & 4.1 & 90.5 & 33.6 & 12.7 & 148.3 \\
\hline $\mathrm{GBGD} \times \mathrm{ECT}$ & 4.2 & 87.9 & 31.1 & 12.8 & 161.6 \\
\hline GBGD $\times$ PHOT & 4.5 & 89.2 & 32.6 & 12.7 & 155.9 \\
\hline ECT & 4.6 & 94.6 & 31.9 & 12.7 & 151.6 \\
\hline $\mathrm{SEm} \pm$ & 0.07 & 1.59 & 0.55 & 0.21 & 2.65 \\
\hline $\mathrm{CD}(\mathrm{P}=0.05)$ & 0.22 & 4.80 & NS & NS & NS \\
\hline
\end{tabular}

Fruit component analysis was carried out by selecting mature nuts (12-months-old) of each hybrid crosses by following the method prescribed by Ratnambal et al. (2000). Copra yield per palm was calculated based on the copra content per nut, expressed as $\mathrm{kg} \mathrm{palm}^{-1}$. The data on different characters were subjected to statistical analysis as per the standard procedures (Panse and Sukhatme, 1985).

\section{Results and discussion}

\section{Growth and reproductive characters}

The palm height and stem girth at the age of 15 years varied significantly among different coconut hybrids (Table 2), and the cross combination, ECT $\times$ GBGD and GBGD $\times$ ECT, recorded the lowest palm height $(4.2 \mathrm{~m})$, while ECT $\times$ MYD recorded the highest palm height $(4.9 \mathrm{~m})$. The girth at one metre height was the highest in ECT $\times$ MYD and LCT $\times$ GBGD $(100 \mathrm{~cm})$. The girth was significantly lower in GBGD $\times$ ECT and GBGD $\times$ PHOT hybrids $(89.2$ and $87.2 \mathrm{~cm})$, which might be due to dwarf female parents. Similar findings were also reported by Nagwekar et al. (2002) and Ramanandam et al. (2017). Higher the girth of the palm favours more accumulation of biomass and hence increases the carbon sequestration potential of the palms (Ghavale et al., 2020). With respect to the number of

Table 3. Reproductive characters of coconut hybrids

\begin{tabular}{|c|c|c|c|c|c|}
\hline $\begin{array}{l}\text { Hybrid cross } \\
\text { combination }\end{array}$ & $\begin{array}{l}\text { Age at first } \\
\text { flowering } \\
\text { (months) }\end{array}$ & $\begin{array}{c}\text { No. of } \\
\text { inflorescences } \\
\text { palm }^{-1} \\
\end{array}$ & $\begin{array}{c}\text { No. of } \\
\text { female flowers } \\
\text { palm }^{-1} \\
\end{array}$ & $\begin{array}{c}\text { Fruit set } \\
\text { percentage }\end{array}$ & $\begin{array}{c}\text { Nut yield } \\
\text { palm }^{-1} \text { year }^{-1} \\
(2019-20) \\
\end{array}$ \\
\hline $\mathrm{ECT} \times \mathrm{MGD}$ & 69 & 12.6 & 271.9 & 32.4 & 88.1 \\
\hline ECT $\times$ MYD & 70 & 12.7 & 283.6 & 32.8 & 93.2 \\
\hline $\mathrm{LCT} \times \mathrm{COD}$ & 69 & 12.5 & 271.6 & 33.6 & 91.3 \\
\hline $\mathrm{LCT} \times \mathrm{GBGD}$ & 64 & 12.5 & 281.0 & 33.3 & 90.3 \\
\hline WCT × MYD & 69 & 12.7 & 279.9 & 31.5 & 87.9 \\
\hline $\mathrm{ECT} \times \mathrm{GBGD}$ & 56 & 12.6 & 286.5 & 38.7 & 108.5 \\
\hline $\mathrm{GBGD} \times \mathrm{ECT}$ & 50 & 12.7 & 285.7 & 31.6 & 90.1 \\
\hline GBGD $\times$ PHOT & 52 & 12.6 & 271.9 & 33.5 & 90.9 \\
\hline ECT & 72 & 12.5 & 231.2 & 34.6 & 80.1 \\
\hline $\mathrm{SEm} \pm$ & 1.09 & 0.21 & 4.80 & 0.57 & 1.57 \\
\hline $\mathrm{CD}(\mathrm{P}=0.05)$ & 3.31 & NS & 14.53 & 1.73 & 4.77 \\
\hline
\end{tabular}


functional leaves, ECT $\times$ GBGD recorded the maximum number of functional leaves on the crown (33.6) and was on par with other hybrids except for GBGD $\times$ ECT. Nampoothiri et al. (1975) reported that the number of leaves present on the crown was positively correlated with yield in coconut. However, annual leaf production and petiole length did not differ significantly among the hybrids.

Regarding age (month) at first flowering, the hybrids showed significant differences for the trait (Table 3). The earliest to flower was GBGD $\times$ ECT cross combination (50 months after planting), and it was on par with GBGD $\times$ PHOT (52 months) followed by ECT $\times$ GBGD (56 months) with regular bearing habit. The earliest flowering was noticed in cross combinations where GBGD (dwarf cultivar) was involved as the female parent; these results are in line with the early reports by Ramanandam et al. (2017) and Sumitha et al. (2020). The total number of female flowers per palm exhibited significant differences among the hybrids evaluated. The highest numbers of female flowers per palm were observed in ECT $\times$ GBGD (286.5) and on par with GBGD $\times \operatorname{ECT}(285.7), G B G D \times$ PHOT $(271.9)$ and
Table 4. Nut yield of coconut hybrids over a period of six years (Nut yield palm ${ }^{-1}$ year $^{-1}$ )

\begin{tabular}{lccc}
\hline $\begin{array}{l}\text { Hybrid cross } \\
\text { combination }\end{array}$ & $\mathbf{2 0 1 4 - 1 6}$ & $\mathbf{2 0 1 6 - 1 8}$ & $\mathbf{2 0 1 8 - 2 0}$ \\
\hline ECT $\times$ MGD & 22.6 & 56.1 & 82.1 \\
ECT $\times$ MYD & 25.5 & 58.7 & 86.9 \\
LCT $\times$ COD & 19.4 & 54.1 & 85.5 \\
LCT $\times$ GBGD & 25.7 & 56.1 & 82.5 \\
WCT $\times$ MYD & 28.4 & 57.5 & 81.9 \\
ECT $\times$ GBGD & 25.4 & 63.0 & 99.1 \\
GBGD $\times$ ECT & 23.2 & 56.2 & 84.1 \\
GBGD $\times$ PHOT & 18.9 & 54.1 & 83.9 \\
ECT & 22.8 & 52.5 & 73.2 \\
\hline
\end{tabular}

ECT $\times$ MYD (283.6). Nut yield in coconut palm can be increased by increasing the number of female flowers per inflorescence, and it is the most important criterion for yield. Hence, improved nut yield (108 nut palm ${ }^{-1}$ ) observed during the present study could be justified. In their study, Kannan and Nambiar (1974) indicated that high yielding hybrids produced a higher number of female flowers. Fruit setting percentage of coconut is an important trait

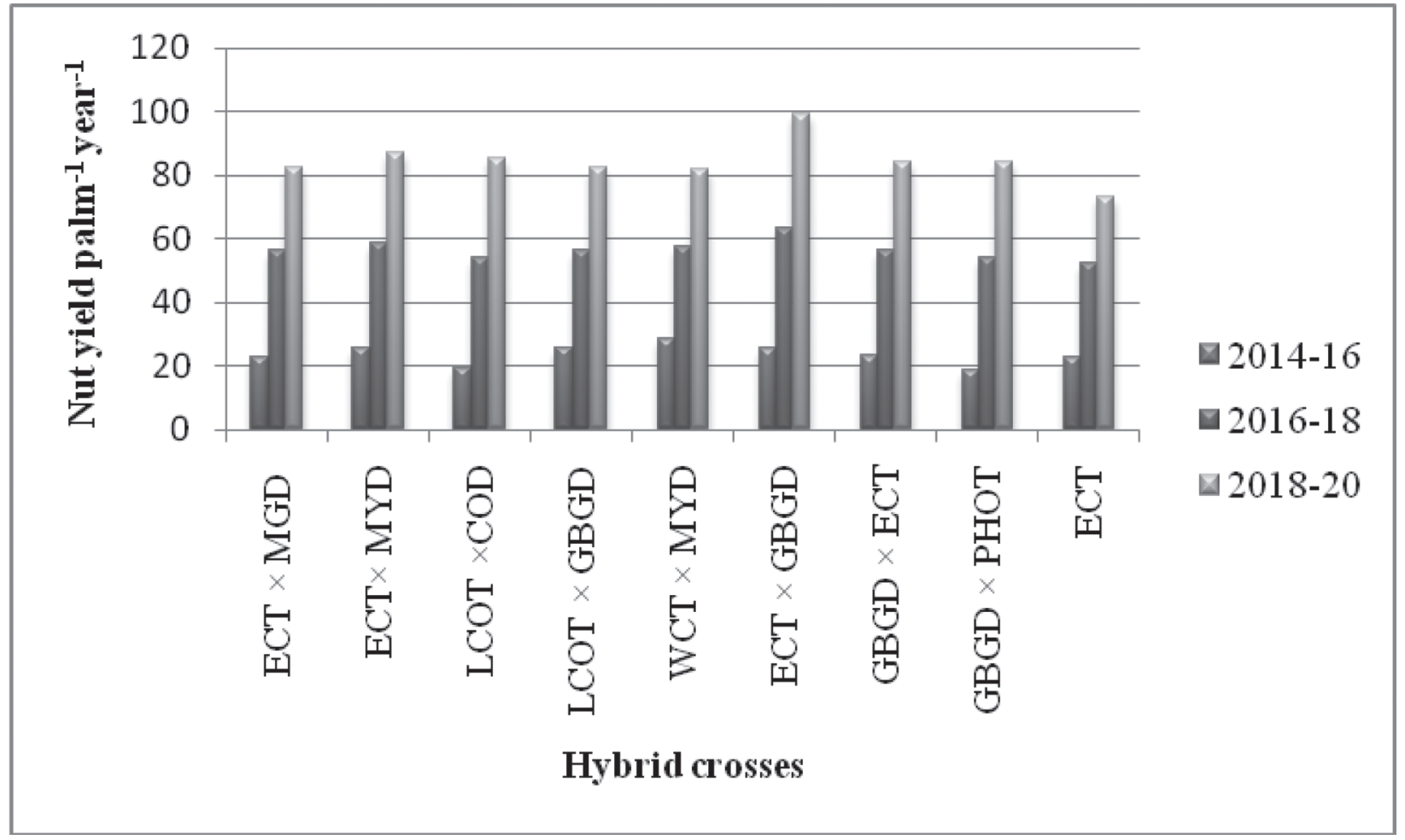

Fig. 1. Nut yield of coconut hybrids over a period of six years 
Table 5. Performance of coconut hybrids for fruit components

\begin{tabular}{|c|c|c|c|c|c|}
\hline $\begin{array}{l}\text { Hybrid cross } \\
\text { combination }\end{array}$ & $\begin{array}{c}\text { Fruit length } \\
(\mathrm{cm})\end{array}$ & $\begin{array}{c}\text { Fruit breadth } \\
(\mathrm{cm})\end{array}$ & $\begin{array}{c}\text { Whole nut weight } \\
\text { (g) }\end{array}$ & $\begin{array}{c}\text { Copra weight } \\
\left(\mathrm{g} \mathrm{nut}^{-1}\right)\end{array}$ & $\begin{array}{c}\text { Copra output } \\
\left(\mathrm{kg} \mathrm{palm}^{-1}\right)\end{array}$ \\
\hline $\mathrm{ECT} \times \mathrm{MGD}$ & 22.9 & 16.1 & 1105.3 & 180.7 & 15.9 \\
\hline $\mathrm{ECT} \times \mathrm{MYD}$ & 22.8 & 14.5 & 1186.0 & 168.7 & 15.7 \\
\hline $\mathrm{LCT} \times \mathrm{COD}$ & 23.6 & 16.2 & 1398.5 & 210.5 & 18.6 \\
\hline $\mathrm{LCT} \times \mathrm{GBGD}$ & 21.9 & 14.9 & 1073.0 & 195.3 & 17.6 \\
\hline WCT $\times$ MYD & 22.6 & 15.1 & 1095.0 & 184.6 & 16.2 \\
\hline $\mathrm{ECT} \times \mathrm{GBGD}$ & 24.2 & 14.9 & 1365.0 & 190.0 & 20.6 \\
\hline $\mathrm{GBGD} \times \mathrm{ECT}$ & 22.1 & 13.5 & 1040.0 & 161.0 & 14.5 \\
\hline GBGD $\times$ PHOT & 23.3 & 15.5 & 1303.7 & 182.3 & 16.6 \\
\hline ECT & 20.1 & 14.2 & 913.5 & 149.5 & 12.0 \\
\hline $\mathrm{SEm} \pm$ & 0.39 & 0.25 & 19.96 & 3.16 & 0.28 \\
\hline $\mathrm{CD}(\mathrm{P}=0.05)$ & 1.18 & 0.78 & 60.35 & 9.57 & 0.87 \\
\hline
\end{tabular}

influencing the nut yield, and in the present study, it was within the range from 31.5 to 38.7 , and the maximum fruit set was obtained in ECT $\times$ GBGD and the lowest in WCT $\times$ MYD. However, variations in the fruit set percentage of different cross combinations in coconut were also observed (Thomas et al., 2012; Nath et al., 2017; Sumitha et al., 2020). In coconut, inter-spadix overlapping of female and male phases is important for fruit set and cross-pollination from nearby palms (Henderson, 1988).

\section{Yield and yield attributing characters}

A wide deviation was observed for nut yield in coconut hybrids (Table 4, Fig. 1) from 2014 to 2020. From 2014 to 2016, the average biennial yield was low due to waterlogging conditions in the field. It was rectified by providing adequate drainage and improved management practices. Among the different hybrid combinations, the mean nut yield per palm during 2018-2020 was significantly higher in ECT $\times$ GBGD (99.1 nuts), which was followed by ECT $\times$ MYD (86.9 nuts) and on par with LCT $\times$ $\mathrm{COD}, \mathrm{GBGD} \times \mathrm{PHOT}, \mathrm{GBGD} \times \mathrm{ECT}$ and LCT $\times$ GBGD. The ECT (local check) recorded 80 nuts palm ${ }^{-1}$ year ${ }^{-1}$. Hybrids under favourable weather conditions and high input management practices have performed better than the local Tall. The high yield potential of the hybrids is mainly due to precocity conferred on the hybrids by their dwarf parents (Bourdeix, 1999; Ohler and Magat, 2001). The number of nuts harvested to the number of female flowers produced is the most important yardstick for consideration. The study indicated that the nut yield in coconut (Table 3 ) could be increased by increasing the production of the female flower per inflorescence (Patel, 1938). Similar results of higher nut yield per palm in hybrids were reported by Sumitha et al. (2020), Shinde et al. (2018), Ramanandam et al. (2017), Nath et al. (2017) and Basavaraju et al. (2011).

The variations obtained in fruit component traits are given in Table 5. The fruit length and fruit breadth were significant among the hybrids, and the highest fruit length was recorded in ECT $\times$ GBGD $(24.2 \mathrm{~cm})$ and was on par with LCT $\times$ COD and GBGD $\times$ PHOT and the lowest was recorded in ECT $(20.1 \mathrm{~cm})$. The fruit breadth ranged from 14.2 to $16.1 \mathrm{~cm}$. Fruit length and breadth are generally greater in the tall palms than dwarfs (Ratnambal et al., 2000). The fruit weight was significantly higher in LCT $\times$ COD (1398.5 g) which was on par with ECT $\times$ GBGD $(1365.0 \mathrm{~g})$. The cross combination LCT $\times$ COD recorded significantly higher copra content $\left(210.5 \mathrm{~g} \mathrm{nut}^{-1}\right)$, followed by LCT $\times$ GBGD $(195.3 \mathrm{~g}$ nut $\left.^{-1}\right)$ and ECT $\times$ GBGD $\left(190\right.$ g nut $\left.^{-1}\right)$. Copra output per palm was significantly higher in ECT $\times$ GBGD $\left(20.6 \mathrm{~kg} \mathrm{palm}^{-1}\right)$ followed by LCT $\times$ COD $(18.6 \mathrm{~kg}$ palm $\left.^{-1}\right)$, while it was significantly low in ECT $\left(12.0 \mathrm{~kg} \mathrm{palm}^{-1}\right)$. Similar observations were also reported by Ramanandam et al. (2018) that higher copra output in ECT $\times$ GBGD could be ascribed to higher nut yield and copra content. 
Table 6. Performance of coconut hybrids for tender nut quality parameters

\begin{tabular}{|c|c|c|c|c|c|}
\hline $\begin{array}{l}\text { Hybrid cross } \\
\text { combination }\end{array}$ & $\begin{array}{c}\text { Volume of water } \\
(\mathrm{mL})\end{array}$ & $\begin{array}{c}\text { TSS } \\
\left({ }^{0} \text { Brix }\right) \\
\end{array}$ & $\begin{array}{l}\text { Total sugar content } \\
\quad\left(\mathrm{g} 100 \mathrm{~mL}^{-1}\right)\end{array}$ & $\begin{array}{c}\text { Sodium content } \\
(\mathrm{ppm})\end{array}$ & $\begin{array}{c}\text { Potassium content } \\
(\mathrm{ppm})\end{array}$ \\
\hline $\mathrm{ECT} \times \mathrm{MGD}$ & 270.3 & 6.7 & 5.0 & 28.7 & 2480.8 \\
\hline $\mathrm{ECT} \times \mathrm{MYD}$ & 325.0 & 6.2 & 4.6 & 27.2 & 2385.0 \\
\hline $\mathrm{LCT} \times \mathrm{COD}$ & 295.0 & 6.5 & 5.4 & 25.4 & 2218.0 \\
\hline $\mathrm{LCT} \times \mathrm{GBGD}$ & 352.4 & 6.9 & 4.8 & 29.7 & 2602.5 \\
\hline WCT $\times$ MYD & 277.6 & 5.8 & 4.6 & 27.5 & 2566.5 \\
\hline $\mathrm{ECT} \times \mathrm{GBGD}$ & 354.1 & 6.9 & 5.6 & 34.0 & 2885.0 \\
\hline $\mathrm{GBGD} \times \mathrm{ECT}$ & 303.1 & 6.1 & 4.9 & 30.5 & 2210.0 \\
\hline GBGD $\times$ PHOT & 362.0 & 6.4 & 4.8 & 28.9 & 2396.6 \\
\hline ECT & 257.0 & 6.3 & 4.4 & 28.5 & 2065.9 \\
\hline $\mathrm{SEm} \pm$ & 5.3 & 0.11 & 0.08 & 0.50 & 42.62 \\
\hline $\mathrm{CD}(\mathrm{P}=0.05)$ & 16.1 & 0.33 & 0.25 & 1.52 & 128.87 \\
\hline
\end{tabular}

\section{Tender nut quality parameters}

The quality and acceptability of tender nut water are influenced by the harvesting time of nut, variety, agro-climatic conditions and management practices. Tender nut water content was significantly higher in GBGD $\times$ PHOT $\left(362.0 \mathrm{~mL}^{\text {nut }}{ }^{-1}\right)$, which was on par with ECT $\times$ GBGD $\left(354.0 \mathrm{~mL} \mathrm{nut}^{-1}\right)$, LCT $\times$ GBGD $\left(352.4 \mathrm{~mL}^{\text {nut }}{ }^{-1}\right)$ and was significantly less in ECT $\left(257.7 \mathrm{~mL} \mathrm{nut}^{-1}\right)$. The TSS was maximum in $\mathrm{ECT} \times \mathrm{GBGD}$ and $\mathrm{LCT} \times \mathrm{GBGD}$ (6.9 $9^{\circ}$ Brix) (Table 6). The sodium and potassium contents of $34 \mathrm{ppm}, 2885 \mathrm{ppm}$ and $29.7 \mathrm{ppm}$ and $2602.5 \mathrm{ppm}$, respectively, were recorded in ECT $\times$ GBGD and LCT $\times$ GBGD cross combinations. The significant difference in quality-related traits might be due to the utilization of GBGD as one of the parents (hybrid combinations). These findings are in concurrence with the previous report from Karnataka by Sumitha et al. (2020), who observed that GBGD $\times$ PHOT and GBGD $\times$ LCT and GBGD $\times$ FJT were better performing hybrids for tender nut purposes as they recorded higher tender nut water, TSS and optimal levels of sodium and potassium.

Coconut improvement through the production of hybrids is a tedious and time-consuming process mainly because of its long gestation period, larger area, and complex resources required for experimentation, and the immediate step is evaluation of already released hybrids to assess their suitability to Odisha conditions. With all the above said quantitative and qualitative characteristics, the hybrids ECT $\times$ GBGD and GBGD $\times$ PHOT released from Andhra Pradesh proved to be the best not only for yield but also for tender nut purposes for the Utkal plain region of Odisha.

\section{References}

Basavaraju, T.B., Palanna, K.B., Lavanya, T.N., Prashanth, M. and Arulraj, S. 2011. Growth and yield performance of coconut hybrids in Maidan tract of Karnataka. Journal of Plantation Crops 39(1): 171-173.

Bourdeix, R. 1999. Coconut varieties: Malayan dwarf. IPGRI COGENT News letter, October 1999, Issue No. 2: 13-15.

CDB. 2020. Coconut Statistics 2019-20. Coconut Development Board, India http://www.coconutboard. gov.in/presentation/statistics.

Chapman, S.C., Cooper, M., Butler, D.G. and Henzell, R.G. 2000. Genotype by environment interactions affecting grain sorghum. I. Characteristics that confound interpretation of hybrid yield. Australian Journal of Agriculture Research 51: 197-207.

de Taffin, G., Zahra, N. and Bonny, C.P. 1991. Dwarf x Tall coconut hybrid performance under commercial conditions in Cote'-d' Ivoire. Oleagineux 46: 194-195.

Ghavale, S.L., Shinde, V.V., Wankhede, S.M., Maheswarappa, H.P. and Haldankar, P.M. 2020. Carbon sequestration and productivity potential of coconut (Cocos nucifera L.) hybrids and varieties under coastal eco-system of Maharashtra. Current Journal Applied Science and Technology 39(22): 30-37.

Jerard, B.A., Niral, V., Samsudeen, K., Nair, R.V., Jayabose, C. and Thomas, G.V. 2015. Development of a Dwarf x Tall coconut hybrid "Kalpa Samrudhi". Journal of Plantation Crops 43(1): 46-52. 
Kannan, K. and Nambiar,P.B.N. 1974. A comparative study of six tall types (Var.Typica) of coconut crossed in the semi tall Gangabondam (Var. javanica). Agricultural Research Journal of Kerala 12: 124-130.

Henderson, A. 1988. Pollination biology of economically important palms. Advances in Economic Botany 6: 36-41.

Nagwekar, D.D., Sawant, V.S., Joshi, G.D., Jamhbale, N.D. and Khan, H.H. 2002. Performance of coconut hybrids under Konkan conditions of Maharashtra. In: Proceedings of Plantation Crops Symposium (PLACROSYM XV), (Eds.) Sridharan, K., Vinod Kumar, P.K., Jayarama and Chulak, B.M., CCRI, Balehonnur, Karnataka, pp. 476-480.

Nampoothiri, K.U.K., Satyabalan, K. and Mathew, J. 1975. Phenotypic and genotypic correlations of certain characters with yield in coconut. FAO. Tech. Wkg. Pty. Coconut Production, Protection and Processing, Kingstom, Jamaica.

Nath, J.C., Deka, K.K., Saud, B.K. and Maheswarappa, H.P. 2017. Performance of coconut hybrid MYD $\times$ WCT in the Brahmaputra valley region of Assam. Indian Journal of Horticulture 74(2): 173-177.

Ohler, J.G. and Magat, S.S. 2001.Cocos nucifera L. In: Plant Resources of South - East Asia No. 14. Vegetable Oils and Fats. (Eds.) Van der Vossen, H.A.M. and Umali, B.E. Bacchius Publishers, Leiden, Netherlands. pp. 76-84.

Patel, J.S. 1938. The Coconut: A Monograph. Madras Government Press, 313 p.

Panse, V.G. and Sukhatme, P.V. 1985. Statistical Methods for Agricultural Workers, ICAR, New Delhi. 381 p.

Ramanandam, G., Ravindra Kumar, K., Padma, E., Kapana, M. and Maheswarappa H.P. 2017. Potential coconut (Cocos nucifera) hybrids for yield and quality for coastal region of Andhra Pradesh (India). Indian Journal of Agricultural Sciences 87(8): 1073-1076.

Ramanandam, G., Padma, E., Kalpana, M., Kurimella, R.K., Rao, N.B.V.C. and Maheswarappa, H.P. 2018. Evaluation of promising hybrids and varieties of coconut in East Coast Region of Andhra Pradesh, International Journal of Pure and Applied Biosciences 6(6): 207-211.

Ratnambal, M.J., Niral, V., Krishnan, M. and Ravikumar, N. 2000. Coconut Descriptors - Part II. Central Plantation Crops Research Institute, Kasaragod, Kerala, India (Compact Disc).

Satyabalan, K. and Vijayakumar, G. 1982. Comparative performance of progenies from Chowghat Dwarf Orange Coconut. Proceedings of PLACROSYM IV, 1981, pp. 289-94.

Shinde, V.V., Ghavale, S.L., Maheswarappa, H.P., Jerard, B.A. and Sumitha, S. 2018. Heterosis for economic traits in coconut (Cocos nucifera L.). Journal of Plantation Crops 46(3): 151-155.

Sumitha, S., Maheswarappa, H.P., Basavaraju, T.B., Prashanth, M. and Swetha. 2020. Potential coconut (Cocos nucifera) hybrids developed using Gangabondam (GBGD) as maternal parent for yield and quality for southern dry tract of Karnataka (India). Indian Journal of Agricultural Sciences 90(8): 1467-1473.

Thomas, R.J., Nair, R.V., Mathews, C., Ajitkumar, R., Sasikala, M. and Nampoothiri, C.K. 2012. Studies on fruit set in coconut upon artificial pollination in various cross combinations. Indian Journal of Horticulture 69: 7-12.

Vijay, S.K., Rajendran, R., Saraladevi, D. and Maheswarappa, H.P. 2017. Evaluation of coconut hybrids developed for high nut and copra. Agriculture Research and Technology 5(4): 55566. DOI:10.19080/ARTOAJ.2017.05.555667. 